DOI: 10.36910/6775-2524-0560-2019-36-19

УДК 602.1:519.85:53.082.9:616-07

${ }^{1}$ Сверстюк А.С., ${ }^{1}$ Багрій-Заяць О.А., ${ }^{1}$ Горкуненко А.Б., ${ }^{1}$ Майхрук З.В., ${ }^{2}$ Гайда В.Я.

${ }^{1}$ Тернопільський національний медичний університет імені І.Я. Горбачевського,

${ }^{2}$ Тернопільський обласний комунальний інститут післядипломної освіти

\title{
КІБЕРФІЗИЧНІ СИСТЕМИ ДЛЯ ВИЗНАЧЕННЯ РІВНЯ ГЛЮКОЗИ
}

\begin{abstract}
Сверстюк А.С., Багрій-Заяць О.А., Горкуненко А.Б., Майхрук 3.В., Гайда В.Я. Кіберфізичні системи для визначення рівня глюкози. У роботі розглянуто фотометричні, біосенсорні, електрохімічні глюкометри. Окремо наведено інсулінову помпу, як метод вимірювання рівня глюкози з можливістю дозованого введення необхідного інсуліну. Наведено схематичне зображення біосенсора ока людини, в який інтегровані аналого-цифровий перетворювач, що перетворює електрохімічні сигнали в цифрові дані, та передавач, який може передавати дані по безпровідній мережі на мобільні пристрої. Запропоновано підхід до розробки кіберфізичної біосенсорної системи для вимірювання рівня глюкози. Наведено функціональну схему кіберфізичної системи для визначення рівня глюкози. В якості результатів чисельного моделювання представлено флуоресціюючі пікселі для проміжного оцінювання рівня глюкози.
\end{abstract}

Ключові слова: кіберфізична система, біосенсор, глюкометри, електронні системи охорони здоров'я

Сверстюк А.С., Багрий-Заяц О.А., Горкуненко А.Б., Майхрук 3.В., Гайда В.Я. Киберфизични системы для определения уровня глюкозы. В работе рассмотрены фотометрические, биосенсорные, электрохимические глюкометры. Отдельно приведены инсулиновую помпу, как метод измерения уровня глюкозы с возможностью дозированного введения необходимого инсулина. Приведенное схематическое изображение биосенсора глаза человека, в который интегрированы аналого-цифровой преобразователь, преобразующий электрохимические сигналы в цифровые данные, и передатчик, который может передавать данные по беспроводной сети на мобильные устройства. Предложен подход к разработке киберфизической биосенсорной системы для измерения уровня глюкозы. Приведенная функциональная схема киберфизической системы для определения уровня глюкозы. В качестве результатов численного моделирования представлены флуоресцирующие пиксели для промежуточного оценивания уровня глюкозы.

Ключевые слова: киберфизична система, биосенсор, глюкометры, электронные системы здравоохранения

Sverstiuk A.S., Bagriy-Zayats O.A., Horkunenko A.B., Mayhruk Z.V., Gaida V.Ya. Cyber-physical systems for glucose determination. Photometric, biosensor, electrochemical glucometers are considered in the work. A separate insulin pump is provided as a method of measuring glucose levels with the ability to dose the required insulin. A schematic illustration of a human eye biosensor incorporating an analog-to-digital converter that converts electrochemical signals into digital data, and a transmitter that can transmit data wirelessly to mobile devices. An approach to the development of a cyber-physical biosensor system for measuring glucose levels is proposed. The functional scheme of the cyber-physical system for determination of glucose level is presented. As the results of the numerical simulation, fluorescing pixels are presented for intermediate estimation of glucose level.

Keywords: cyber-physical system, biosensor, glucometers, electronic health systems

Вступ. Сьогодні активно розвивається концепція створення кіберфізичних систем (КФС) для різноманітних сфер людської діяльності. КФС розглядаються як інтелектуальні системи, в яких інтегровано фізичні об'єкти, зовнішні пристрої, процесори, мережеве обладнання. Основна мета створення КФС - контроль за поведінкою фізичних об'єктів як компонентів таких систем у реальному часі. Це системи, в яких відбувається взаємодія кібернетичних засобів (вимірювальних, обчислювальних, комунікаційних, керуючих, виконавчих) 3 фізичними процесами у довільних об'єктах $[1,2]$. Перспективним є поширення концепції КФС на біомедичну галузь. У таких КФС фізичні об'єкти - це біооб'єкти (БО): від найпростіших до людини включно. Моніторинг поведінки БО кібернетичними методами, автоматичне отримання їх параметрів і характеристик у реальному часі забезпечують надійну взаємодію з БО, а специфіка використання та фізичні особливості БО визначають особливості проектування та розроблення відповідних КФС.

Аналіз останніх досліджень та публікацій. Сьогодні біосенсори активно застосовуються у багатьох сферах людської діяльності. Перш за все, це медична діагностика, зокрема лабораторний аналіз, контроль інтенсивної терапії, а також проведення аналізів у домашніх умовах. Іншою великою галуззю застосування біосенсорів є моніторинг довкілля, а саме контроль води, повітря щодо наявності токсичних хімічних сполук [3]. Широко застосовуються такі пристрої у біотехнології, зокрема у контролі процесів ферментації [4]. У харчовій промисловості біосенсори застосовуються як у контролі самого виробництва, так і у контролі якості та свіжості продукції [5]. Крім того, біосенсори використовуються у системах безпеки (для виявлення наркотиків та вибухових речовин), а також у криміналістиці [6].

Сенсори медичного призначення становлять найбільшу частину ринку біосенсорів. Окрім глюкози медичні біосенсори використовуються для визначення інших метаболітів для діагностики різноманітних порушень обміну речовин, до яких окрім цукрового діабету належать подагра, підвищений вміст холестерину у крові та ін. Такі сенсори створено для визначення сечовини [7], 
сечової кислоти [8], лактату [9.], креатиніну [10], гормонів [11] та інших речовин. Створено також сенсори для діагностики інфекційних захворювань. Біосенсори застосовуються для розв'язання як прикладних задач, так теоретичних проблем хімії білків та нуклеїнових кислот [12].

Основна частина. Батьком біосенсорики і автором першого у світі біосенсорного пристрою $€$ професор біохімії Л. Кларк, який у 1956 році запропонував електрод для визначення кисню у біологічних зразках. Електрод мав просту конструкцію і складався з платинового та срібного дротів, занурених у трубку з рідким електролітом, які відділялися від аналізованого зразка газопроникною мембраною. У 1962 році Кларк вдосконалив запропонований ним раніше кисневий електрод, іммобілізувавши на його поверхні живу біологічну макромолекулу - фермент глюкозооксидазу. Відомо, що глюкозооксидаза каталізує реакцію окислення глюкози до глюконової кислоти, в результаті якої із середовища поглинається кисень і утворюється перекис водню. Цю реакцію можна контролювати за допомогою кисневого електроду. Сьогодні ці роботи вважаються початком всієї біосенсорної технології.

Перевагами ферментного електроду порівняно 3 класичними біохімічними методами вимірювання різноманітних метаболітів (зокрема кисню, глюкози та лактату) були швидкість аналізу, а також можливість проведення вимірювань у біологічних зразках без будь-яких попередніх маніпуляцій та оброблення аналізованого зразку. Л. Кларк відзначав не тільки простоту самої ідеї, а й простоту процесу конструювання створеного ним біосенсора. Для експериментів був потрібен лише розчин солі, срібний та платиновий дроти, впаяні у скляну трубку, джерело живлення, два резистори, целофанова плівка, гальванометр та фермент глюкозооксидоза [13].

Глюкометри допомагають контролювати важливі параметри і стежити за станом здоров'ям. Існує три типи глюкометрів: електрохімічні; біосенсорні; фотометричні. Всі вони інвазивних за принципом дії, тобто для визначення концентрації глюкози в крові необхідно проколоти шкіру.

Фотометричні глюкометри використовуються в якості портативних пристроїв для контролю рівня цукру в крові. Хоча ці моделі вже дещо застаріли, вони часто використовуються в якості лабораторного обладнання. Принцип їх роботи полягає у визначенні глікемії на основі зміни кольору тест-зони на тест-смужці під впливом глюкози. Результати аналізуються спеціальної оптичної системою, після чого виводяться на дисплей. На тубус 3 смужками також нанесена відповідна шкала, за допомогою якої можна візуально оцінити отримані дані. Перевагими фотометричних глюкометрів є компактність розміру корпусу, легкість і зручність користування. До недоліків слід віднести те, що оптична система приладу досить тендітна і вимагає догляду, кінцеві результати вимірювань неточні і залежать від навичок, регулярності та правильності догляду, впливу різних зовнішніх факторів (рівня освітлення, температури і т. п.).
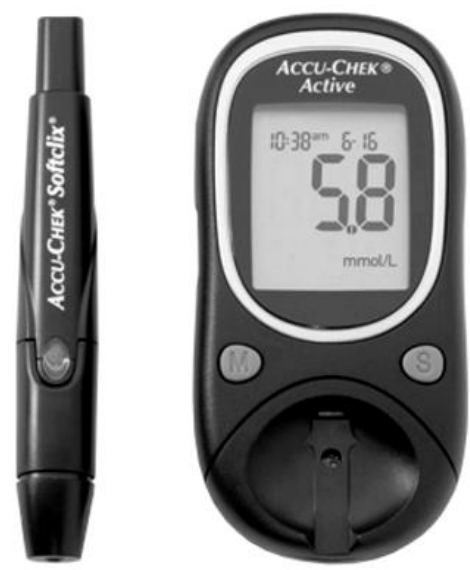

Pис.1.Глюкометр Acси-Chek Active

Біосенсорні глюкометри теж працюють з тест-смужками, але іншої якості і принципу дії. Крапелька крові наноситься на тест-смужку і автоматично всмоктується. Після чого відбувається складний хімічний процес i виробляється слабкий електричний імпульс, який реєструється пристроєм.

Переваги біосенсорних глюкометрів є більш точні результати в порівнянні 3 оптичними моделями (вплив зовнішніх факторів зведено до мінімуму); надійність; легкість використання; 


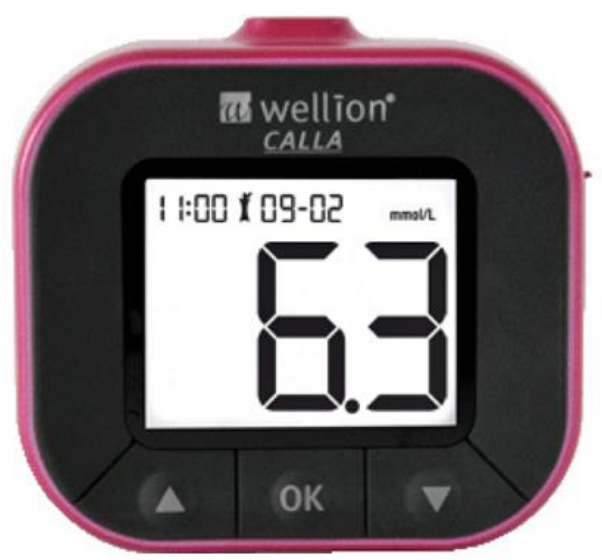

Pис.2. Глюкометр Wellion Calla Light

У електрохімічних глюкометрів $є$ два способи діагностики: амперометрія - визначає глікемію відповідно до величини струму, який виникає при реакції спеціальних компонентів тестсмужки з глюкозою; кулонометрія - заснована на підрахунку загального заряду електронів при аналогічному процесі.

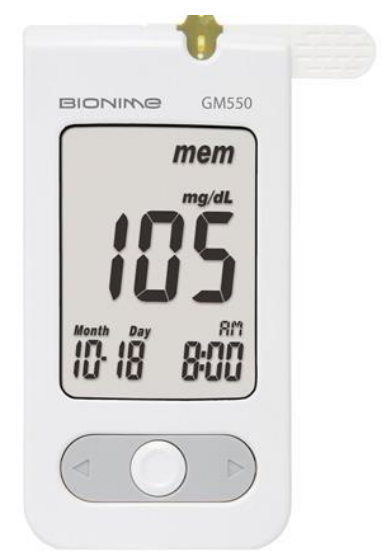

Pис.3. Глюкометр Bionime Rightest GM550.

Стимулом до бурхливого розвитку біосенсорики були потреби медицини. Першим біосенсором був глюкозний біосенсор, створений для швидкого визначення рівня глюкози у крові в домашніх умовах у хворих на цукровий діабет, який $\epsilon$ небезпечним через його ускладнення, що виникають при несвоєчасному корегуванні рівня глюкози у крові. До найбільш небезпечних ускладнень діабету належать порушення кровообігу, погіршення зору та гіперглікемічна кома. Зважаючи на це такі пацієнти потребують щоденного контролю та корегування рівня цукру у крові. Оскільки медицина є платоспроможним споживачем, уже через 14 років після створення Кларком лабораторного прототипу глюкозного біосенсору компанія Yellow Springs Instruments створила перший в світі комерційний глюкометр. Сьогодні глюкометри різних модифікацій випускаються великою кількістю фірм, є досить доступними і користуються великим попитом населення.

Інсулінова помпа - сучасний засіб введення інсуліну, який сприяє більш швидкій і кращій нормалізації цукру в крові та попереджає виникнення гіпоглікемій і ускладнень цукрового діабету (ЦД).

У комплект приладу входять:

1. Помпа - насос, призначений для подачі інсуліну.

2. Комп'ютер з вбудованою системою управління.

3. Картридж, що містить інсулін (змінний).

4. І Інфузійний набір. Він складається з катетера для введення інсуліну та системи трубок, що з'єднують помпу і канюлю.

5. Батарейки.

Принцип роботи помпи (Рис.4) подібний до функції підшлункової залози, тому введення ліків відбувається в базальному i болюсному режимі. Швидкість надходження базальної дози 
72 Науковий журнал "Комп'ютерно-інтегровані технології: освіта, наука, виробництво" Луиььк, 2019. Випуск № 36

програмується пристроєм і може змінюватися через півгодини. Наприклад, кожні 5 хвилин надходить 0,05 одиниць гормону (при швидкості 0,6 ОД/год).

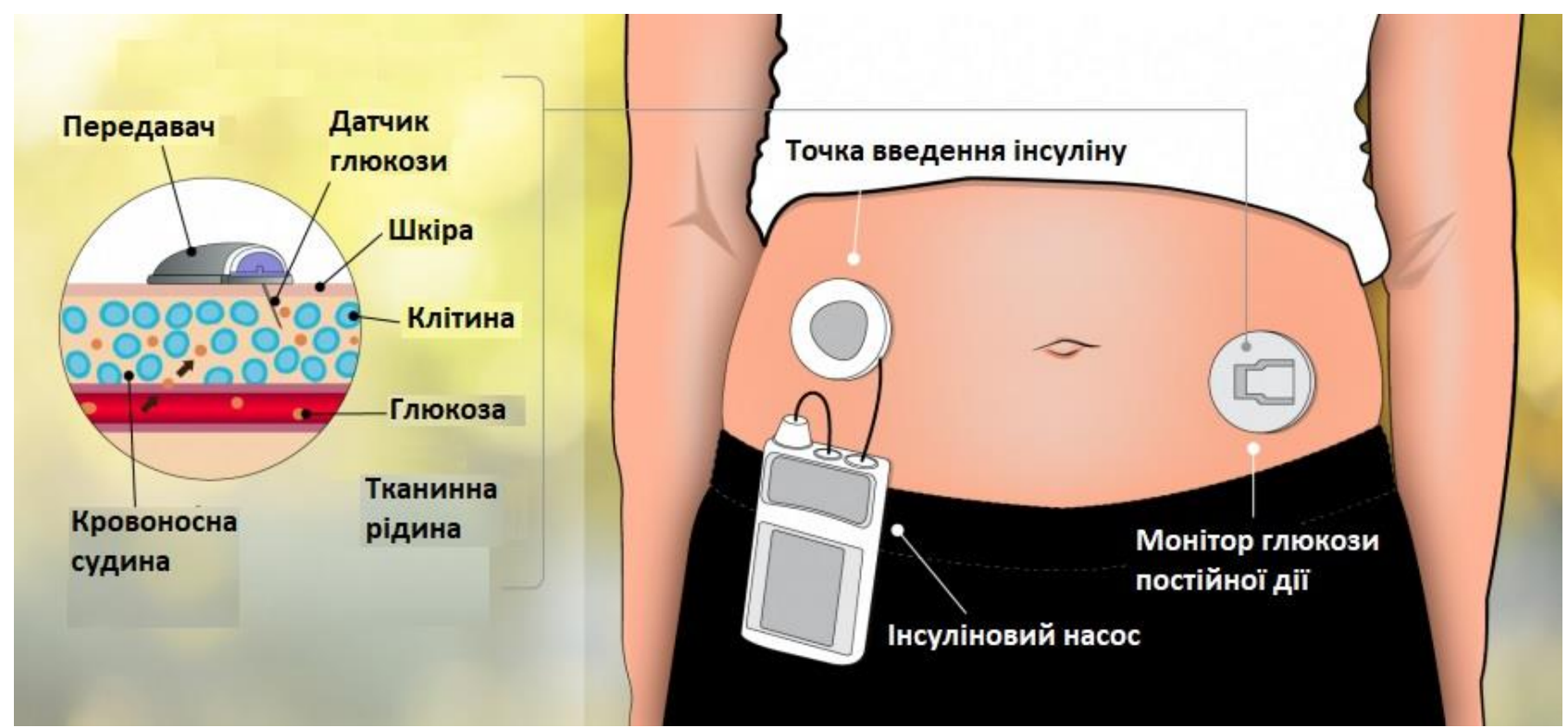

Рис.4. Принциип роботи інсулінової помпи

Подача ліків залежить від моделі приладу і здійснюється в невеликій кількості (доза становить від 0,025 до 0,1 ОД). Болюсна доза повинна вводитися пацієнтами вручну перед кожним перекусом. Крім того, прилади дають можливість встановити спеціальну програму, що забезпечує разове надходження певної кількості гормону, якщо значення цукру в цей момент перевищує норму.
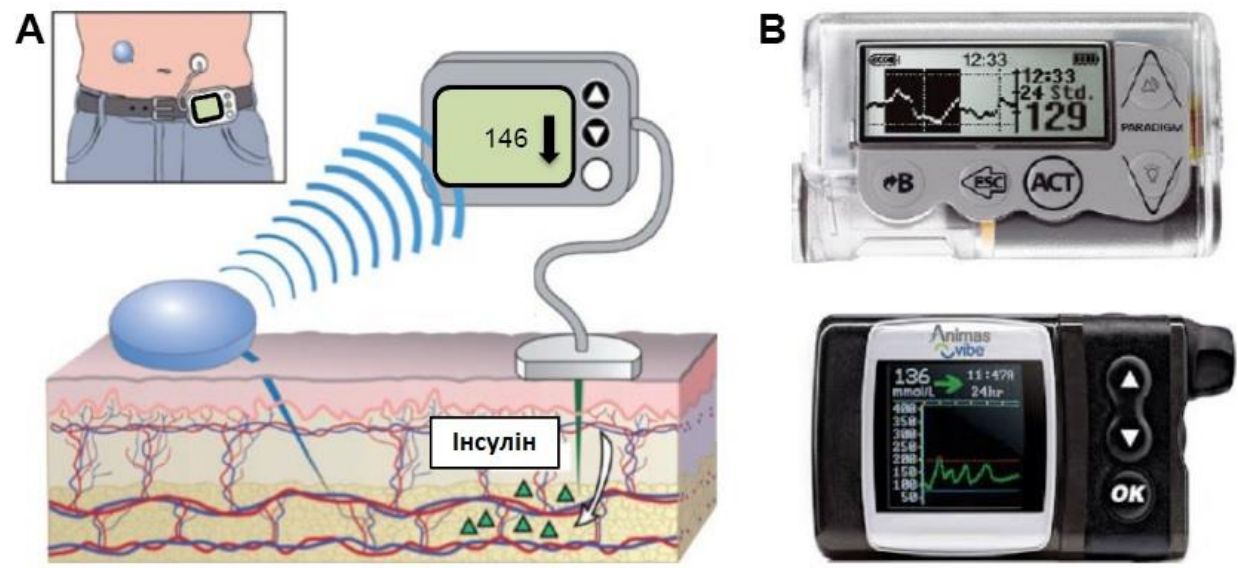

Рис.5. (А) Датчик глюкози (В) Пристрої для терапії інсуліновими насосами з датчиком.

На рис.5 (А) зображено датчик глюкози в реальному часі, який розміщують на поверхні шкіри 3 його наконечником, введеним в тканинну інтерстиціальну рідину, вимірює рівні глюкози. Значення глюкози передається на інсулінову помпу радіочастотою.

Замість аналізу проб крові, біосенсор здатен безперервно вимірювати рівень глюкози через аналіз таких рідин, як піт чи сльози. Один із таких сенсорів розробляється в інституті Фраунгофера (FraunhoferInstitut eforMicroelectronicCircuitsandSystems - IMS). 


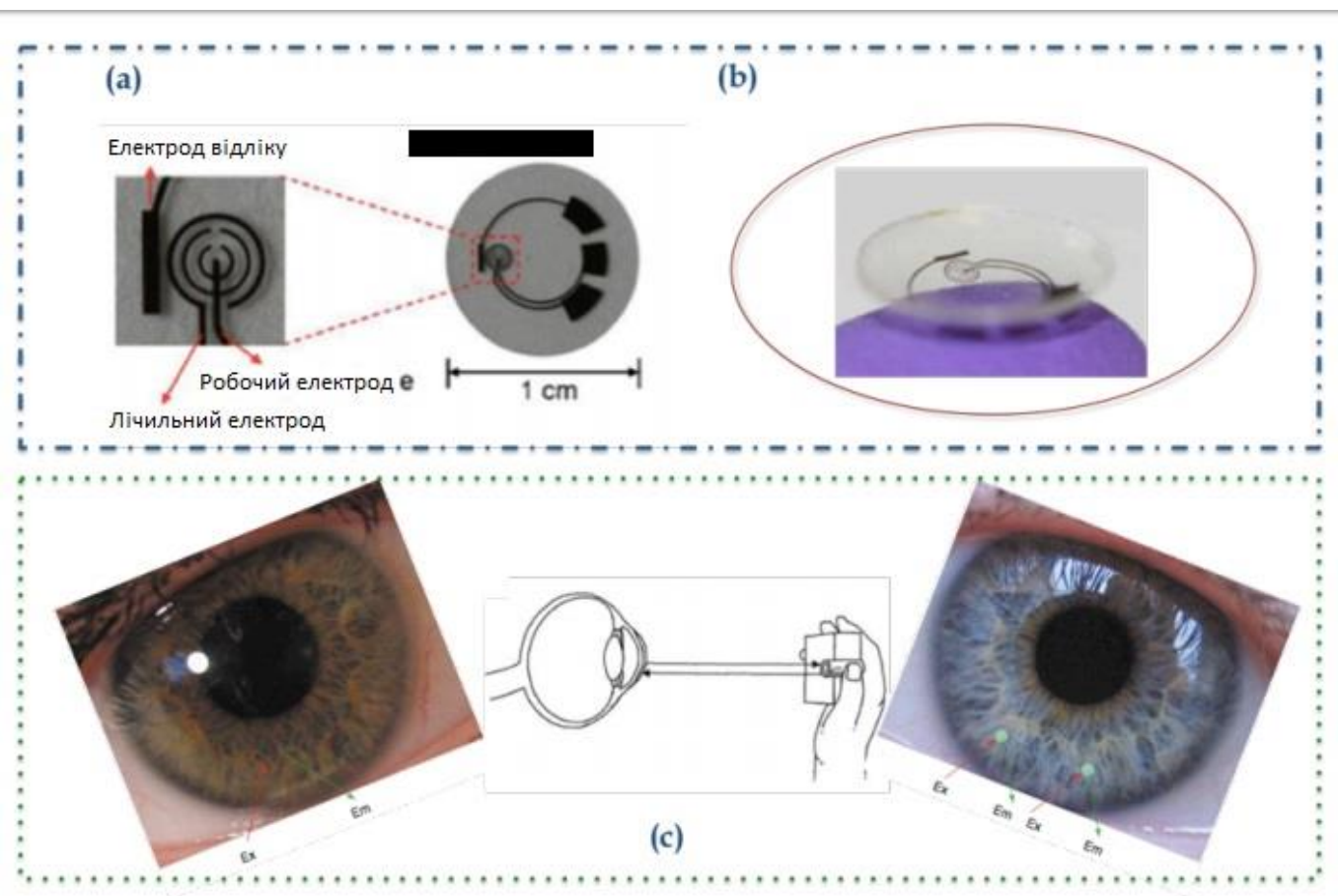

Рис. 6. Біосенсор ока людини [14]

В той час як сама ідея біосенсорів не нова, однак перші розробки таких пристроїв були дуже великими, неточними та споживали багато енергії. Новий біосенсор складається з чіпа, розмір якого становить 0.5 х 2 мм та яких споживає менше 100 мікроампер при п’яти вольтовому живленні. Чіп пристрою інтегрує нанопотенціометр, що вимірює концентрації перекису водню $\left(\mathrm{H}_{2} \mathrm{O}_{2}\right)$ та інших хімічних речовин, які виникають в наслідок електрохімічної реакції. Реакція виникає за допомогою ферменту - глюкозооксидази (GOx). Пристрій використовує концентрації цих хімічних речовин для розрахунку рівня глюкози пацієнта. Також в пристрій інтегровані аналого-цифровий перетворювач, що перетворює електрохімічні сигнали в цифрові дані, та передавач, які може передавати дані по безпровідній мережі на мобільні пристрої.

Інший біосенсор був розроблений датською компанією NovioSense [15]. Він встановлюється між повікою та оком та має технологію вимірювання схожу 3 вищеописаною. NovioSense BV складається 3 декількох провідників, що з'єднуються у формі пружини та утворюють мікроелектрохімічний осередок.

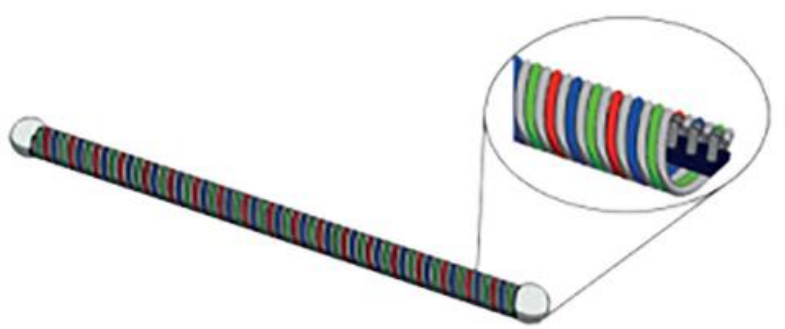

Puc. 7. Схема пристрою NovioSense BV.

Спіральна форма надає пристрою гнучкості та може відповідати певному контуру для моніторингу параметрів навколишнього середовища. Корпус нано-потенціометру виконаний у вигляді пустотілого осердя котушки та нано-чіпів в якості передавачів, які дають змогу передавати результати вимірювань на мобільні пристрої. Захисний шар біосенсора складається з гідрогелю, що утворює гладку поверхню, завдяки чому пристрій може бути використаний в якості зручного неінвазивного моніторингу.

Функціональна схема кіберфізичної біосенсорної системи (КФБСС). У роботі [16] запропоновано загальну структуру КФСС. При застосуванні цього підходу у випадку імуносенсорів 
74 Науковий журнал "Комп'ютерно-інтегровані технології: освіта, наука, виробництво" Луиььк, 2019. Випуск № 36

можна виокремити три види завдань: отримати загальну інформацію про імуносенсор; виміряти імунологічні показники 3 перетворенням одиниць та калібруванням; взаємодіяти 3 іншими імуносенсорами.

У роботах [17-20] проведено розробку та дослідження КФБСС.

В основі функціональної схеми КФБСС для вимірювання рівня глюкози (зовнішній прямокутник на рис. 1) покладено концепцію КФСС з врахуванням особливостей інтелектуальних біосенсорів.

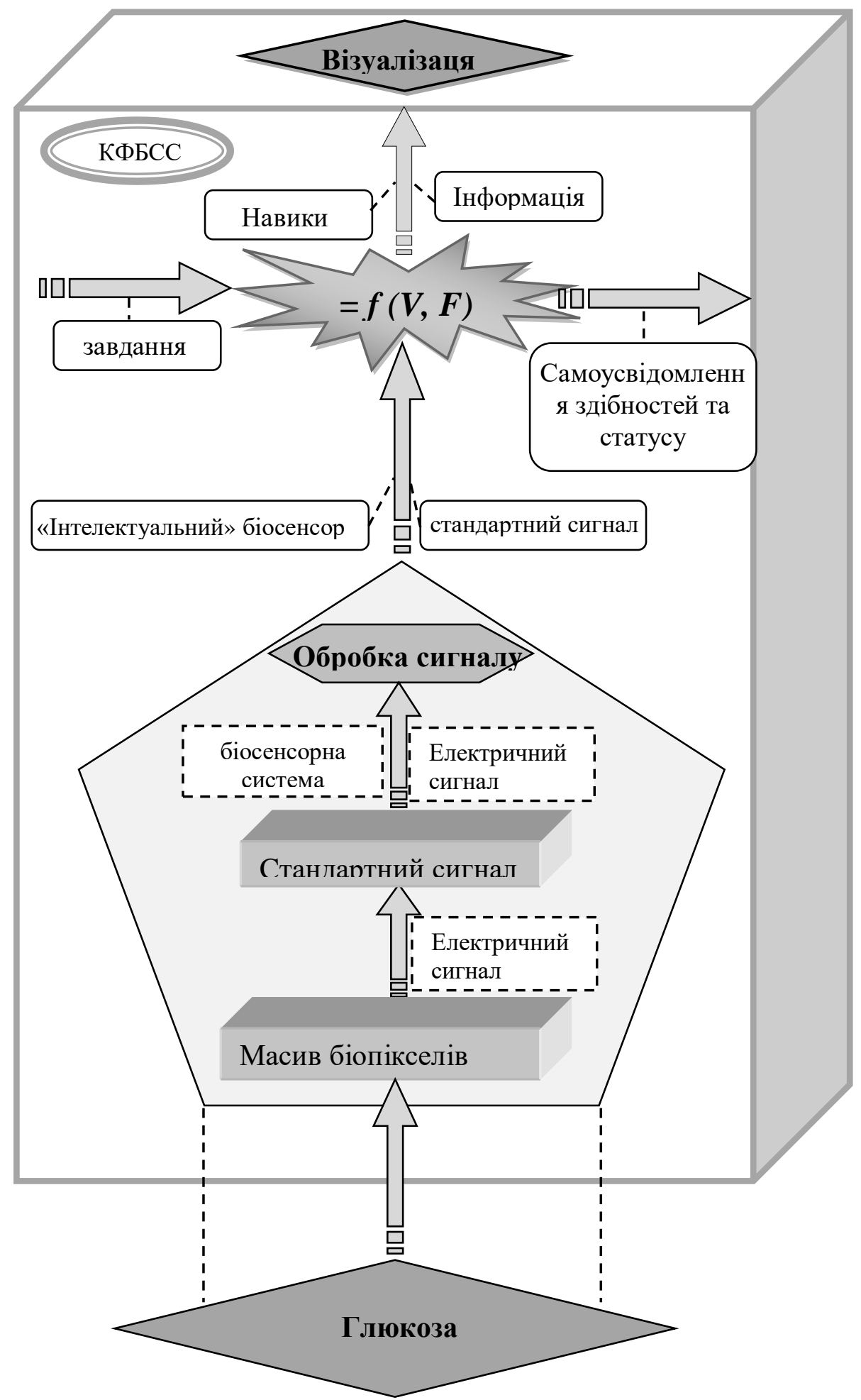

Рисунок 8. Функціональна схема КФБСС 
3 додатковими навиками (пунктирна лінія на рис. 8) імуносенсор розширюється до КФБСС.

На рис. 9 наведено результат чисельного моделювання КФБСС у вигляді вираженої біжучої хвилі флуорисценціюючих пікселів. Явище флуорисценції виникає в результаті вимірювання рівня глюкози.
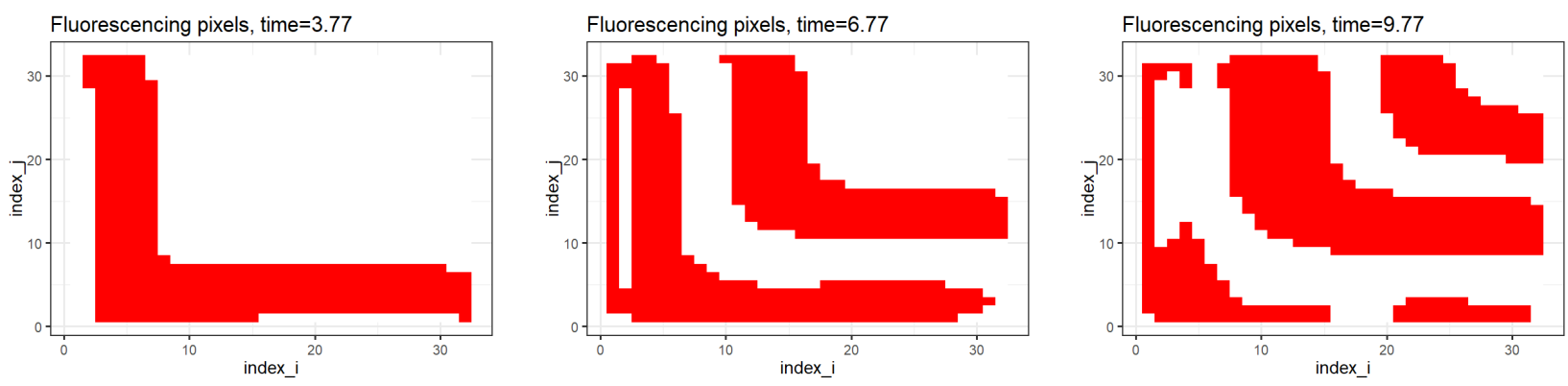

Рисунок 9. Зображення флуоресиениії в КФБСС.

Для контролю та керування процесом вимірювання у КФБСС надзвичайно велике значення має результат комп'ютерного моделювання флуоресціюючих пікселів, що дає змогу оцінити їх кількість та, в кінцевому випадку, вимірюваний рівень глюкози.

Висновки. Біосенсорика є важливою галуззю сучасної аналітичної біотехнології, нагальна потреба у якій зумовлена необхідністю створення простих у застосуванні пристроїв для контролю стану здоров'я людини, а також контролю якості води, продуктів харчування, безпечності довкілля у режимі реального часу у домашніх чи польових умовах. Перспективним напрямком розвитку біосенсорики $є$ створення високо стабільних сенсорних пристроїв на основі штучних аналогів біологічних рецепторів, що поєднують високу селективність при розпізнаванні різноманітних аналітів з високою стабільністю, властивою синтетичним матеріалам за жорстких умов зберігання та використання. В роботы запропоновано підхід до розробки КФБСС для вимірювання рівня глюкози. Наведено функціональну схему та результати чисельного моделювання флуоресціюючих пікселів для проміжного оцінювання рівня глюкози. Одним 3 найважливіших напрямків розвитку сучасної біосенсорики є неінвазивна діагностика, яка не передбачає пошкодження шкіри чи слизових оболонок при відборі проб для аналізу.

\section{Список бібліографічних посилань.}

1. Мельник А.О. Кіберфізичні системи: проблеми створення та напрями розвитку. Вісник Нац. ун-ту Львівська політехніка. 2014. № 806: Комп’ютерні системи та мережі. С. 154-161.

2. Anatoliy Melnik. Cyber-physical systems multilayer platform and research framework. Advances in cyber-physical systems. Volume1.Number1,2016, pp.1-6.

3. Nanomaterial-Based Biosensors for Environmental and Biological Monitoring of Organophosphorus Pesticides and Nerve Agents / W. Zhang, A. M. Asiri, D. Liu, et al. TrAC Trends in Analytical Chemistry. 2014. Vol. 54. P. 1-10.

4. Various Instrumental Approaches for Determination of Organic Acids in Wines / J. Zeravik, Z. Fohlerova, M. Milovanovic, et al. Food Chemistry. - 2016. Vol. 194. P. 432-440.

5. Arugula M. A. Biosensors for Detection of Genetically Modified Organisms in Food and Feed / M. A. Arugula, A. L. Simonian. Genetically Modified Organisms in Food. - 2016. - P. 97-110.

6. Biosensors in Forensic Analysis. A Review / P. Yáñez-Sedeño, L. Agüí, R. Villalonga, et al. Analytica Chimica Acta. 2014. - Vol. 823. - P. 1-19.

7. Creatinine and Urea Biosensors Based on a Novel Ammonium Ion-Selective CopperPolyaniline Nano-Composite / M. Zhybak, V. Beni, M.Y. Vagin, et al. // Biosensors and Bioelectronics. - 2016. - Vol. 77. - P. 505-511.

8. Ghosh T. A Novel Third Generation Uric Acid Biosensor Using Uricase Electro-Activated with Ferrocene on a Nafion Coated Glassy Carbon Electrode / T. Ghosh, P. Sarkar, A. P. Turner Bioelectrochemistry. - 2015. - Vol. 102. - P. 1-9.

9. Biosensors Based on Electrochemical Lactate Detection: A Comprehensive Review / K. Rathee, V. Dhull, R. Dhull, et al. // 69 ISSN 0374-3896 Наука та наукознавство, 2016, № 3 Biochemistry and Biophysics Reports. - 2016. - Vol. 5. -P. $35-54$.

10. Application of Creatinine-Sensitive Biosensor for Hemodyalisis Control / O. A. Zinchenko, S. V. Marchenko, T. A. Sergeyeva, et al. Biosensors and Bioelectronics. 2012. Vol. 35. P. 466-469.

11. Bahadır E. B. Electrochemical Biosensors for Hormone Analyses / E. B. Bahadır, M. K. Sezgintürk. Biosensors and Bioelectronics. - 2015. - Vol. 68. - P. 62-71.

12. Comparison of Biosensor Platforms in the Evaluation of High Affinity AntibodyAntigen Binding Kinetics / D. Yang, A. Singh, H. Wu, et al. Analytical Biochemistry. - 2016. -Vol. 508. - P. 78-96.

13. Clark Jr L.C. Electrode Systems for Continuous Monitoring in Cardiovascular Surgery / L. C. Clark Jr, C. Lyons . Annals of the New York Academy of Sciences. 1962. Vol. 102. P. 29-45.

14. Quick D. Non-invasivewaytomonitorbloodglucoselevelsusinglight. — Режим доступа: http://www.gizmag.com/ — Дата доступу: 23.03.2016. 
76 Науковий журнал "Комп'ютерно-інтегровані технології: освіта, наука, виробниџтво" Луцьк, 2019. Випуск № 36

15. Wood C. Finalpieceofthediabetespuzzleopensthedoortobetterscreening. — Режим доступа: http://www.gizmag.com/ — Дата доступа: 12.05.2016.

16. Characterization of Cyber-Physical Sensor Systems [Text] / [C. Berger, A. Hees, S. Braunreuther, G. Reinhart] // Procedia CIRP. 2016. Vol. 41. P. 638-643

17. Martsenyuk V. Cyber-physical model of the immunosensor system at the hexagonal lattice with the use of differential equations of the population dynamics / A. Sverstiuk . Innovative Technologies and Scientific Solutions for Industries. - 2019. - № 1. p.75-83.

18. Сверстюк А.С. Моделювання кібер-фізичної імуносенсорної системи на прямокутній решітці 3 використанням решітчастих диференціальних рівнянь із запізненням / А.С. Сверстюк . Сенсорна електроніка та мікросистемні технології. 2019. - № 2. С. 53-65.

19. Сверстюк А.С. Про кібер-фізичну модель імуносенсорної системи на прямокутній решітці 3 використанням різницевих рівнянь популяційної динаміки / А.С. Сверстюк . Вісник ТНТУ. 2018. - № 4. - С. 147-161.

20. Марценюк В.П. Про модель кібер-фізичної системи 3 атаками стану та вимірювань на основі стохастичних різницевих рівнянь / А.С. Сверстюк .Захист інформації. 2019. Том 21, № 1. с.5-12. 